\title{
BIOMASS TECHNOLOGY PRODUCTION FROM AGRO-PROCESSING WASTES BY AN EXPELLER MACHINE
}

\author{
Mohamed I. Shoughy*
}

\begin{abstract}
An extruder was developed and tested for forming biomass from agroprocessing wastes. The experimental treatments included four screw speeds $(0.789,1.05,1.41$ and $1.57 \mathrm{~m} / \mathrm{s}$.), four die hole diameters of extruder (6, 8, 10 and 12mm) and three moisture levels (7.5, 10.5 and $13.6 \%$ ) of two agro-processing wastes at different particle size (sawmill dust $(\leq 3 \mathrm{~mm})$ and coarser corncob grinds $(\leq 6.5 \mathrm{~mm})$. The results of the experiments showed that the particle size had a significant effect on machine productivity, pellets density, durability and specific energy requirement. The finer sawdust resulted in higher productivity, pellets density, durability and lower specific energy than the coarser corncob grinds. The machine productivity of sawdust was higher value by about $7 \%$ than the productivity of corncobs. The pellets density ranged from 0.81 to $1.24 \mathrm{~g} / \mathrm{cm}^{3}$ for sawdust and form 0.76 to $0.94 \mathrm{~g} / \mathrm{cm}^{3}$ for corncobs. The durability of sawdust pellets was higher by about $15.6 \%$ for corncobs pellets. While, the energy requirement of sawdust pellets was lower value by about $41.7 \%$ than for corncobs pellets. The pellets produced on the smallest die and lower moisture content had the best quality values. The combustion test indicated that the combustion of the pellets is more regular than the combustion of loose materials and provided the highest flue gas temperature and low carbon monoxide contents emitted.
\end{abstract}

\section{INTRODUCTION}

The interest in producing energy from biomass has increased in recent years, owing to depleting fossil energy supplies and

climate change caused by carbon emissions. Low densities of $40-$ $60 \mathrm{~kg} / \mathrm{m}^{3}$ for lignocellulosic and $200-400 \mathrm{~kg} / \mathrm{m}^{3}$ for woody biomass limit their application for energy purposes.

\footnotetext{
*Agric. Eng. Res. Ins. (AEnRI), Dokki, Giza, Egypt. E-Mail: Shoughy_AERI@Yahoo.com
} 
Prior to use in energy applications these materials need to be densified (Sokhansanj et al., 2006 and Hess et al., 2009). The densified biomass can have bulk densities over 10 times the raw material, improves its handling characteristics, reduces transportation cost, enhances its volumetric calorific value, and produces a uniform, clean, stable fuel, or an input for further refining processes Granada et al., (2002). Due to the advantages of densification, several biomass materials have been experimentally studied to convert to densified fuels for example: rice husk, peanut shell, coconut fiber and palm fruit fiber, Chin and Siddiqui (2000). On average 2.5 tons of biomass on a dry basis have an energy potential equivalent to one ton of oil, El-Saeidy (2004). The most common residential fuel pellets in developed nations are made from sawdust and ground wood chips, which are by-products generated from furniture, lumber, and other industries. Corncobs also are one of the potential agriculture biomass feedstock for renewable energy industries to abate the current energy and the greenhouse gas problems. Corncobs can be used for producing heat, power, gas/fuels liquid and a wide variety of chemical productions such as furfural, xylitol and activated carbon. It can be used without pelleting for majority of applications such as industrial scale heating, Jin and Wang (2011). However, for applications required high quality feedstock such as home heating, corncobs may need to be pelleted. Furthermore, although corn cubs are almost cylindrical in shape, a mixture of whole and broken pieces of cobs may result due to breakage of cubs during corn combine harvesting and mechanical shelling, may lack free-flowing properties. Fuel pellets can be used in pellet burning fireplaces or stoves for residential use or burned in solid fuel boilers for industrial use. Most developed and industrialized nations are looking into developing technologies to use biomass more efficiently. Sweden has decided to phase out nuclear plants, reduce fossil fuel energy usage, and increase the use of biomass for energy (Bjorheden, 2006). Literature review showed that different biomass materials required different optimum conditions for pelleting process. Sokhansanj et al., (2005) concluded that the optimum moisture content for pelleting cellulosic materials is $8-12 \%$, whereas for starch and protein materials, the optimum moisture content can range up to $20 \%$. Mani et 
al., (2006) reported that the particle size has significant effect on the mechanical properties of pellets. Saptoadi (2006) found that the best results of combustion, the pellets dimensions should be as small as possible with coarse particle size. Kaliyan and Morey (2007) indicated that temperatures of around $85^{\circ} \mathrm{C}$ can occur in conventional ring-die pelleting machines due to frictional heating. Chevanan et al., (2010) revealed that the specific mechanical energy was found to be lowest for the $15 \%$ moisture content and highest at $20 \%$ moisture content. Tumuluru et al., (2010b) found that a larger die diameters of $7.2 \mathrm{~mm}$ produced less-durable pellets compared to a smaller die diameter of $6.4 \mathrm{~mm}$. However, very small particle sizes can lead to jamming of the pellet mills and affect production capacity. The failure of several pelleting or briquetting projects (either technically or financially) in developing countries was mainly due to mismatching equipment to suit the specific characteristics of raw materials. Before selecting or designing any commercial machine, it is necessary to know the mechanical behavior of the material and the processing conditions. To increase production and a size reduction process, there is a need to develop more efficient mechanical screw pelletizer. We successfully developed and tested a machine for forming rice bran pellets, Shoughy et al., (2011). The objectives of the present work were to:

Testing and evaluating an expeller machine used for rice bran pellets as a dual purpose for forming biomass pellets from agro-processing wastes.

Study the effect of some operating parameters such as screw speed, die hole diameter of extruder and particle size of two agro-processing wastes (sawmill dust and corncobs) at various moisture levels on machine productivity, specific energy requirement and pellets quality (pellets density and durability) as well as flue gas temperature and gas emission during combustion test.

\section{MATERIALS AND METHODS}

Materials:

Two types of agro-processing wastes (corncobs and sawmill dust) were used for the experiments. The ground corncobs sample were obtained after mechanical shelling at Sakha Research Station, Corn Section, Kafrelsheikh Governorate after 2012 summer harvesting season. While, 
grounds sawmill dust was fine particles size of wood obtained from local medium scale workshops in Kafrelsheikh, as a by-product generated from furniture and other wood industries. In the production of woody pellets from sawdust; a particle size of approximately $\leq 3.0 \mathrm{~mm}$ is used. While, a particle size of coarser corncobs grinds of approximately $\leq 6.4 \mathrm{~mm}$ is used. All of the samples were subsequently ground using a forage grinder with a screen opening sizes of $3-7 \mathrm{~mm}$. The authors decided to use these screen size based on the studies conducted by Adapa et al., (2009).The initial moisture contents of the ground corncubs and sawdust was 7.5 and $6.8 \%$ (w.b.), respectively. The moisture content (MC, \%) of the samples were raised to 7.5, 10.5 and $13.6 \%$ (w.b.) by adding and sprinkling calculated amount of water and subsequently stored the samples in plastic bags in a cold room kept at $4{ }^{\circ} \mathrm{C}$ for a minimum of $72 \mathrm{~h}$.

\section{Equipment:}

An expeller machine which successfully developed, modified and tested in Agriculture Engineering Research Institute for forming rice bran pellets are used to form biomass from agro-processing wastes. The extrusion process can be made continuous by a helical screw. Material is fed into an inlet hopper and moved forward by rotation of the screw. As it reaches the die, the pressure increases to the level required to force the material through the die holes. The rotating screw transports material from inlet to discharge as a result of the slipping of material on the screw surface. The friction between material and screw surface results in shearing and heating of the material. The original die outlet head has a chuck like outlet that changed and replaced by an outlet ring die have 20 , 16, 14 and 12 round holes for forming biomass pellets at different diameters $(6,8,10$ and $12 \mathrm{~mm}$, respectively) by extrusion process, where the function of the chuck of the original outlet die to permit a final adjustment of pressure and capacity. Also, the barrel was modified to fit with biomass pelleting. The clearance between the flat steel bars inside the barrel (cage) was eliminated and the bars also sloped towards the die hole of the extruder by reducing the bars cross section in order to rise up the compression action of the screw towards the die holes of extruder to 
increase the extruder die work area. More details of this machine and their modification are found in Shoughy et al., (2011).

\section{Experimental treatments}

The performance of the extruder machine such as productivity and the required energy was evaluated. Pellets quality was also evaluated through the pellets density and durability as well as the combustion characteristics. The experimental treatments, included four levels of screw speed $(0.79,1.05,1.4$ and $1.57 \mathrm{~m} / \mathrm{s})$, four levels of die hole diameter $(6,8$, and $10,12 \mathrm{~mm})$ and two different types of agro-processing wastes (corncobs $(\leq 6.5 \mathrm{~mm})$ and sawmill dust $(\leq 3 \mathrm{~mm}))$ at three moisture levels $(7.5,10.5$ and $13.6 \%)$.

\section{Test procedure and measurements:}

Before each experiment, the samples were prepared at desired moisture content and the experimental run as follow:

1. Before pelleting operation the hopper was filled with the sample $(2 \mathrm{~kg})$.

2. The pelleting machine was run.

3. The consumed time from the instant of dropping until the instant of complete discharge was measured.

4. Samples were taken periodically from the machine outlet and placed in ambient air to natural cooling and drying.

5. After average of three replicated of this procedure was taken with the two studied wastes at various moisture content, the amount of biomass pellet was determined. Then the machine productivity, $\mathrm{kg} / \mathrm{h}$ and specific energy requirement, $\mathrm{kW} . \mathrm{h} / \mathrm{ton}$ were estimated for each test. The quality of the biomass pellets (pellet density, $\mathrm{kg} / \mathrm{m}^{3}$ and durability index, \%) and combustion characteristics was also evaluated.

\section{Measurements:}

\section{Moisture content:}

The moisture content, \% was determined using $\boldsymbol{A S A E}$ (2004), where oven drying of the samples was carried out at $103{ }^{\circ} \mathrm{C}$ for $24 \mathrm{~h}$.

\section{Machine productivity:}

Raw material was manually fed into the feed hopper at a uniform rate to prevent blockage at the entrance to the barrel. During experiments, 
extrudates samples were collected at 30s intervals and the mass flow rate through the extruder was then calculated, $\mathrm{kg} / \mathrm{h}$ as follows:

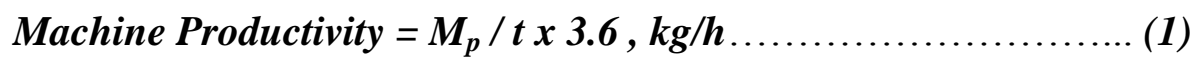

Where: $M_{p}=$ pellets yield mass, $\mathrm{g} ;$ and $t=$ consumed time, $\mathrm{s}$.

\section{Power consumption:}

The electric power consumption for each test was measured by using an electrical meter, model (GG150E) having an accuracy of $1 \%$, which connected at the source of power supply. Then the actual power of the machine was estimated according to Uppal (1984) as follows:

$$
\text { Power consumption }=\sqrt{ } 3 \cdot I_{L} \cdot N_{L} \cdot \eta \cdot \cos \varphi / 1000, \mathrm{~kW}
$$

Where: $\mathrm{I}_{\mathrm{L}}=$ electric current, ampere,

$\mathrm{N}_{\mathrm{L}}=$ electric potential, volt, being equal to 360 volt,

$\eta=$ mechanical efficiency $(95 \%)$; and

$\operatorname{Cos} \varphi=$ power factor $(0.85)$.

\section{Specific energy requirements:}

It was evaluated by calculating the consumed power, $\mathrm{kW}$ then divided by the machine productivity, $\mathrm{kg} / \mathrm{h}$ :

Energy requirements $=$ Power/Extruder productivity, $\mathrm{kW} . \mathrm{h} / \mathrm{kg}$

\section{Biomass pellets quality:}

1. Pellet density, $\mathbf{g} / \mathbf{c m}^{3}$ : Density is an important property of the fuel. High density products are desirable in terms of transportation, storage and handling. The density of the agro-processing pellets biomass was determined by measuring dimensions and weights of 10 samples. Weight measurements were performed with an electronic balance and the dimension of the samples was determined by using a Vernier caliper. The average density was calculated and reported.

2. Pellet durability index: It was determined according to $A S A E$ (2004). Extrudates $(500 \mathrm{~g})$ were tumbled inside a pellet durability tester, model (Seedburo) for 10min and sieved through a No. 6 screen. Pellet durability index was calculated as follow:

$$
\text { Durability }=\left(M_{a} / M_{b}\right) \times 100, \%
$$


Where: $M_{a}$ and $M_{b}$ are mass (g) of pellets retained on the screen after and before tumbling, respectively.

\section{Combustion test:}

To evaluate combustion characteristics, $100 \mathrm{~g}$ samples were placed over the hearth of the locally made stove and the burning tests were carried out at the atmospheric condition with the experimental materials previously described in the form of loose materials and pellets at recommended condition $(6 \mathrm{~mm}$ diameter and $7.5 \%$, w.b., moisture content). Flue gas temperatures and carbon monoxide content (CO) were recorded during tests by using the flue gas analyzer. A gas sensor was installed centrally in the exhaust gate as described by El-Saeidy (2004).

\section{Statistical Analysis:}

The analysis of variance was employed in this experimental work to examine the effect of operating parameters on the extruder productivity, energy requirements and biomass pellets quality.

\section{RESULTS AND DISCUSSIONS}

\section{Machine productivity, $\mathbf{k g} / \mathbf{h}$ :}

The unusually high production rate might have prevented extradites from becoming adequately conditioned. Even though the pellet extruder was able to handle this large production rate, the pellets were lower in quality. The extruder productivity was increased with increasing screw speed and die hole diameter, while it was decreased with increasing moisture content of two wastes as shown in Fig. 1. At the same hole diameter (6 $\mathrm{mm}$ ), the extruder productivity of sawdust was increased by 25.8, 28.7, $41 \%$ and with corncobs by $28.8,34.4,37.3 \%$ when screw speed increased from 0.785 to $1.57 \mathrm{~m} / \mathrm{s}$ at moisture contents of $7.5,10.5$ and $13.6 \%$, respectively. Also, at the same screw speed $(1.57 \mathrm{~m} / \mathrm{s})$, the productivity of sawdust was increased by $35.3,32.9,30.9 \%$ and with corncobs by $39.2,43.9,36.5 \%$ when the die hole diameter increased from 6 to $12 \mathrm{~mm}$, respectively with the same moisture levels mentioned above. While, at the same screw speed $(1.57 \mathrm{~m} / \mathrm{s})$ and die hole diameter $(6 \mathrm{~mm})$, the extruder productivity of sawdust and corncobs was decreased by 8.8 and $10.3 \%$ with increasing moisture levels from 7.5 to $13.6 \%$, w.b, respectively. The same trend was noticed with various operating 
parameters, but the productivity of sawdust in average was higher by about $7 \%$ than the productivity of corncobs. This increase in pelletizer productivity with the increase of screw speed may be due to the increase of material quantities which passed through the extrusion and expelled from the die hole at the same time. The higher screw speeds generally result in higher mass flow rates as reported by Chevanan et al., (2010). This behavior was expected because drag flow in extruders has been shown to be directly proportional to screw speed and higher screw speeds generally result in higher mass flow rates. The productivity was increased with the increase of die hole diameters due to the increase of output area that help the pellets to move out the die holes quickly, resulting remarkable decrease consumed time of treatment. While, productivity decreased by increasing moisture levels because of the inherent variability in the physico-chemical properties of the raw materials.

\section{Pellets density, $\mathbf{g} / \mathrm{cm}^{3}$ :}

The pellets density was increased with increasing screw speed, while it was decreased with increasing die hole diameter and moisture levels of the two studied wastes as shown in Fig. 2. At the same die hole diameter ( $6 \mathrm{~mm}$ ), the pellets density of sawdust was increased by 48.3, 43.4, $41.7 \%$ and with corncobs by $31.4,46.5,55.1 \%$ when screw speed increased from 0.785 to $1.57 \mathrm{~m} / \mathrm{s}$ at moisture contents of $7.5,10.5$ and $13.6 \%$, respectively. While, at the same screw speed $(1.57 \mathrm{~m} / \mathrm{s})$, the pellets density of sawdust was decreased by 20.2, 14.8, 13.5\% and with corncobs it was decreased by $26.4,23.8,17.6 \%$ when the die hole diameter increased from 6 to $12 \mathrm{~mm}$, respectively with the same moisture levels mentioned above. Moreover, at the same screw speed $(1.57 \mathrm{~m} / \mathrm{s})$ and die hole diameter $(6 \mathrm{~mm})$, the pellets density of sawdust and corncobs was decreased by 12.1 and $8.2 \%$ with increasing moisture levels from 7.5 to $13.6 \%$, w.b, respectively. The same trend was noticed with various operating parameters, but the pellets density of sawdust in average was higher by about $20.7 \%$ than the average pellets density of corncobs. This result may be due to the fine size particles of sawdust wastes are more compressible and fill the void spaces better than the coarser corncobs particles and thus increase the pellets density. 


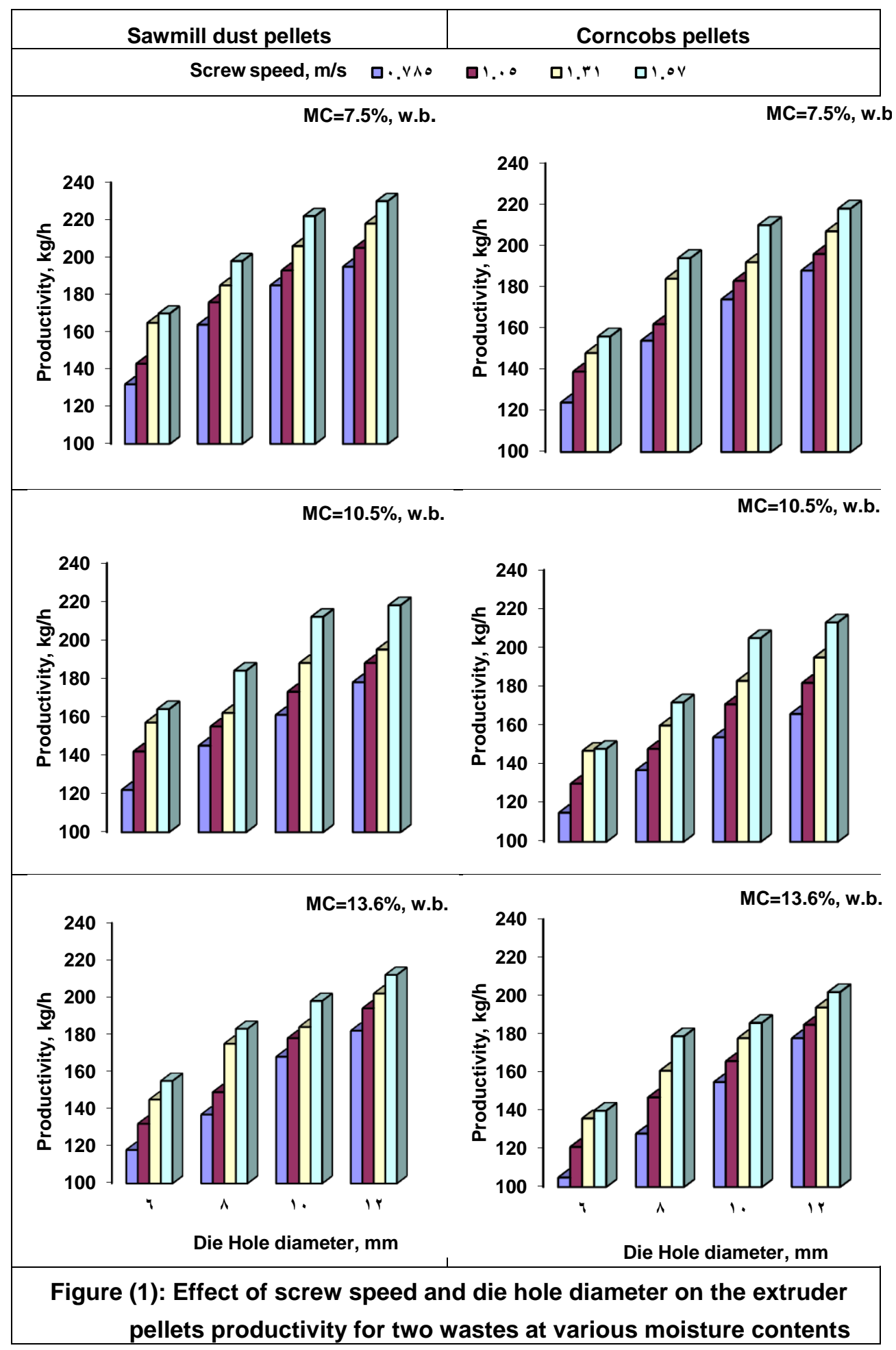


Mani et al. (2006) found that biomass from woody plants contains higher percentages of resins and lignin compared to agricultural crop residues (corncobs, straw and stover). High pressures and temperatures during densification due to increasing screw speed and friction causes during pressing process may develop solid bridges by a diffusion of molecules from one particle to another at the points of contact, which increases density.

When lignin-rich biomass is compacted under high pressure and temperature, lignin becomes soft exhibiting thermosetting properties (Van Dam et al., 2004). Moisture content also plays a major role in determining density and strength of the densified masses. They also reported that maximum pellet density of $\left(1238.1 \mathrm{~kg} / \mathrm{m}^{3}\right)$ was observed in the moisture of $5 \%$ for prickly lettuce, while it reduced to $\left(926.5 \mathrm{~kg} / \mathrm{m}^{3}\right)$ at the moisture content of $20 \%$. The decrease in pellets density with increasing die hole diameter could be attributed to the applied pressure was not enough to compact the pellets and less friction suffered by the biomass materials passing through the 10 and $12 \mathrm{~mm}$ die diameter. The woody particles of sawdust are heavier than the fibers corn cubs. In addition, literature review on the effect of grind size on compact density indicated the production of high density and high quality pellets at finer grind sizes pellets with different moisture contents (Mark, 2008 and Adapa et al., 2009).

\section{Pellet durability index, \%:}

Durability is an important property of granulated biomass pellets for storage, transportation and ultimately for combustion. Durability of the best pellets must be not lower than $97-98 \%$. The results in Fig. 3 show that pellets durability was increased with increasing screw speed and moisture levels of wastes, while it was decreased when increasing die hole diameter of the extruder. The pellets produced on the smallest die had the best durability values. At the same hole diameter $(6 \mathrm{~mm})$, durability of sawdust was increased by $15.2,10.3$ and $12.5 \%$ and with corncobs it was increased by $20.1,31.7,21.4 \%$ when screw speed increased from 0.785 to $1.57 \mathrm{~m} / \mathrm{s}$ at moisture levels of $7.5,10.5$ and $13.6 \%$, respectively. 


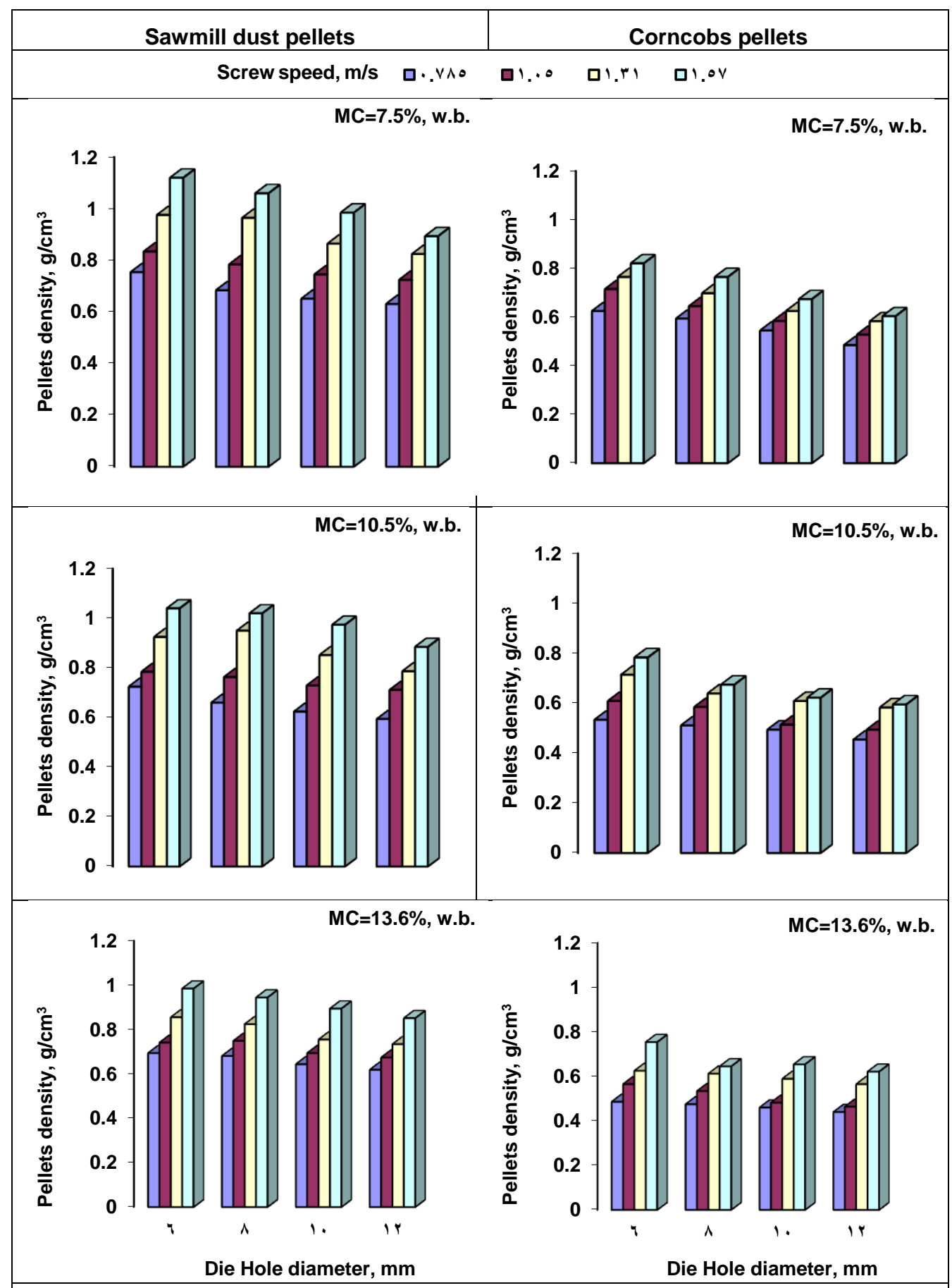

Figure (2): Effect of screw speed and die hole diameter on pellets density for two wastes at various moisture contents. 
Also, at the same screw speed $(1.57 \mathrm{~m} / \mathrm{s})$, the durability of sawdust was decreased by $16.1,12.5,9.1 \%$ and it was decreased for corncobs by 18.8 , $18.1,16.1 \%$ when the die hole diameter increased from 6 to $12 \mathrm{~mm}$, respectively with the same moisture levels mentioned above. While, at the same screw speed $(1.57 \mathrm{~m} / \mathrm{s})$ and die hole diameter $(6 \mathrm{~mm})$, the pellets density of sawdust and corncobs was increased by 7.6 and $8.8 \%$ with increasing moisture levels from 7.5 to $13.6 \%$, w.b, respectively. In fact, Kaliyan and Morey (2007) stated that moisture acts both as a binder and a lubricant. The same trend was noticed with various operating parameters, but the pellets durability of sawdust in average was higher value by about $15.6 \%$ than the pellets durability of corncobs. Woody plants contain lignin which contributes to the strength characteristics of densified pellets and briquettes. The heat produced during densification assists the release of lignin which then acts as a natural binder for the material. Lignin present in the biomass acts as a glue and improve the binding characteristics of the biomass. Also, Kaliyan and Morey (2006) found that increasing moisture content from 10 to15\% (w.b.) increased the briquette durability from 62 to $84 \%$. They also reported that, binding of the fines in the pellet is assisted by starch gelatinization during heating of the extruded ingredients. These results were agreed with the data obtained by Shukla et al. (2005) and Chevanan et al., (2007). They reported that changing the level of moisture content of the ingredient blends had a significant effect on extrudates pellets durability index. They also reported that increasing the moisture content from 15 to $25 \%$ resulted in an increase in extrudates pellets durability index by $8.7 \%$. The increase of pellets durability by increasing screw speed and moisture levels could be attributed to the increase in pellets compression in the die zone, as well as increasing the temperature which remove the moisture from the cells between the granules, that make the pellets too hard with high resistance against cracking and breakage. Meanwhile, as noticed by Tumuluru et al. (2010a), the decrease of pellets durability index by increasing die hole diameter of extruder could be due to increasing the output area which decreases pressure in die extrusion, it means low level of pellets compaction and high amount of air between the granules. They also mentioned that higher percentage of extractives (waxes, resins, and 
starches) and lignin in the bark could have helped increase the bonding and the overall pellet strength. This may probably due to the differences in the chemical composition, and the amounts of lignin, hemicelluloses, and extractives of the wood species. Moisture content also had a negative effect on the durability of pellets made with or without preheating; increasing the moisture content from $5 \%$ to $20 \%$ decreased the durability of the biomass materials. Lignin is the component that permits adhesion in the wood structure, and is a rigidifying and bulking agent as reported by Thomas (2010). Also, Granada et al., (2002) stated that the moisture level $(8-15 \%)$ in pellets will reduce the softening temperature of lignin form 140 to $100-135^{\circ} \mathrm{C}$ by plasticizing the molecule chains. Also, water helps in promoting bonding forces by increasing the true area of contact of the particles. The right amount of moisture develops self-bonding properties in lignocelluloses substances at elevated temperatures and pressures prevalent in pelleting machines. Also, some biomass tends to fuse together better than other biomass. Sawdust is an especially suitable feedstock for pelleting because the high lignin content that is naturally present in the wood acts as a glue to hold the pellet together, while corncobs with high fibers content tend to not fuse nearly as well, and the resulting pellets are less dense and more easily broken during handling process.

\section{Specific energy requirements, $\mathrm{kW} \mathrm{h} / \mathrm{kg}$ :}

The energy requirements of pellets depend theoretically on the consumed power and productivity, while depend practically on the effect of operating parameters such as screw speed and die hole diameter of extruder as well as waste particle size and moisture levels. The results in Fig. 4 show that the specific energy requirement of the extruder was increased with increasing screw speed and wastes moisture levels. While, it was decreased when increasing die hole diameter. At the same die hole diameter $(6 \mathrm{~mm})$, the energy requirements was increased by $13.8,8.8$, $8.3 \%$ for sawdust and by $9.4,12.5,7.1 \%$ for corncobs when screw speed of the extruder increased from 0.785 to $1.57 \mathrm{~m} / \mathrm{s}$ at moisture levels of 7.5 , 10.5 and $13.6 \%$, respectively. Also, at the same screw speed $(1.57 \mathrm{~m} / \mathrm{s})$, the energy requirement of sawdust pellets was decreased by $32.9,35.8$, 
$35.2 \%$ and it was decreased with corncobs pellets by $37.5,36.7,37.1 \%$ when the die hole diameter increased from 6 to $12 \mathrm{~mm}$, respectively with the same moisture levels mentioned above. While, at the same screw speed $(1.57 \mathrm{~m} / \mathrm{s})$ and die hole diameter $(6 \mathrm{~mm})$, the energy requirement of sawdust and corncobs was increased by 27.3 and $22.1 \%$ with increasing moisture levels from 7.5 to $13.6 \%$, w.b, respectively. The same trend was noticed with various operating parameters, but the energy requirement of sawdust in average was lower value by about $41.7 \%$ than energy requirement for corncobs. Less energy was required to compress the wastes with higher bulk and particle densities like sawdust. The increase in energy requirements by increasing screw speed could be due to the higher increase in power consumption and at the same time the slower increase in production rate. Also, the increase in energy requirements by increasing moisture contents could be due to more torque required rotating the extruder screw with high moisture extrudates as reported by Chevanan et al., (2010). Meanwhile, the decrease of energy requirements by increasing die hole diameter may be due to the increase of output area that caused a decrease in the required power, and the increase of the production rate in the same time.

\section{Combustion test:}

Carbon monoxide content emitted and the flue gas temperature had been monitored during the burning test of pellets at $6 \mathrm{~mm}$ diameter of two agro-processing wastes with $7.5 \%$ moisture content as a recommended diameter and moisture content. Their average values are presented in Table 1. The highest flue gas temperature was found in sawdust pellets $\left(78.4^{\circ} \mathrm{C}\right)$ and $\mathrm{CO}$ reduced by about $50 \%$ as compared to loose materials of two agro-processing wastes. The combustion of pellets is more regular than the combustion of loose materials due to the high density of the pellets. Also Sokhansanj et al., (2005) reported that the combustion of dense granulated and uniformly sized biomass can be controlled more precisely than loose, low bulk density biomass and thus reduce emissions. 


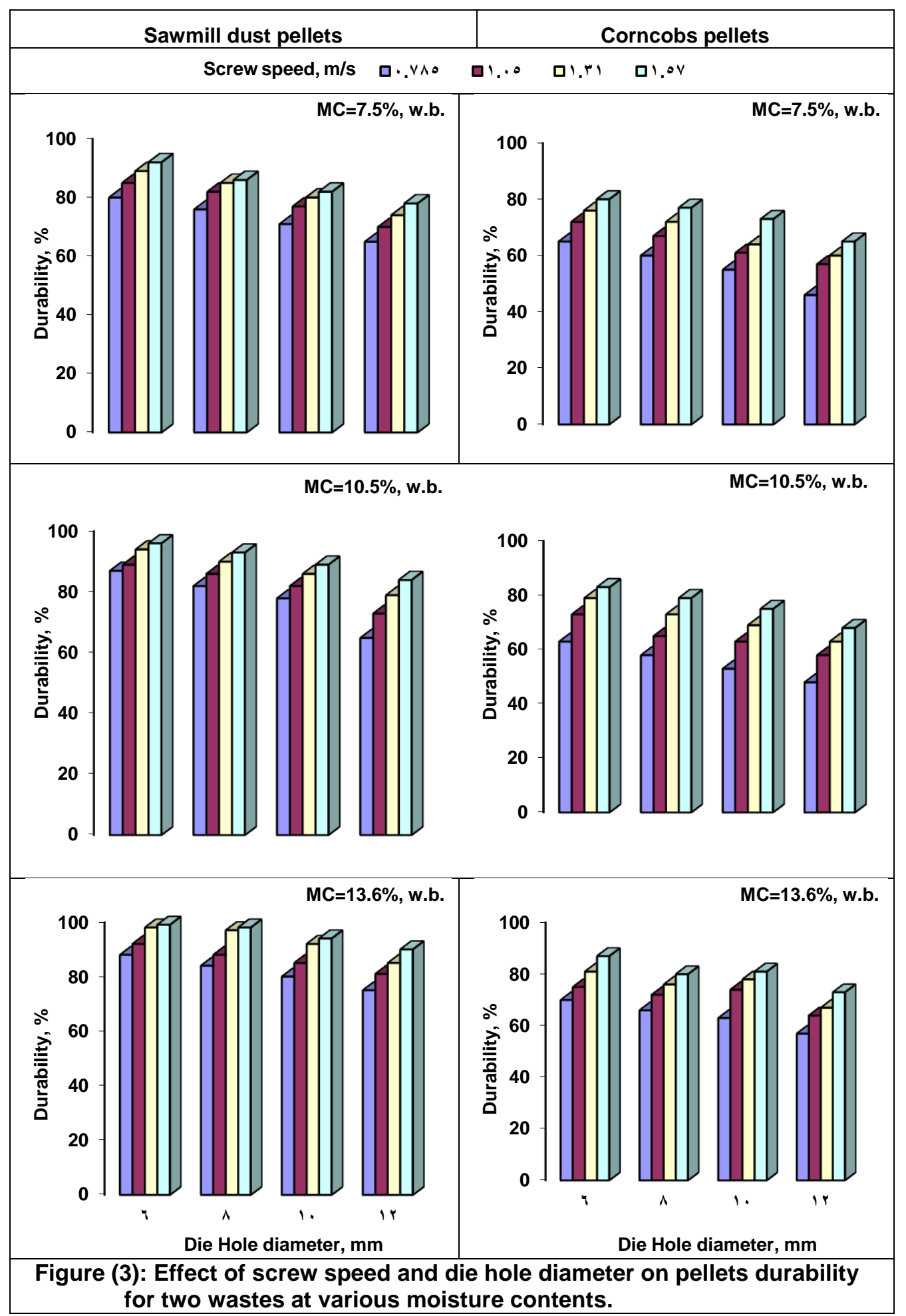




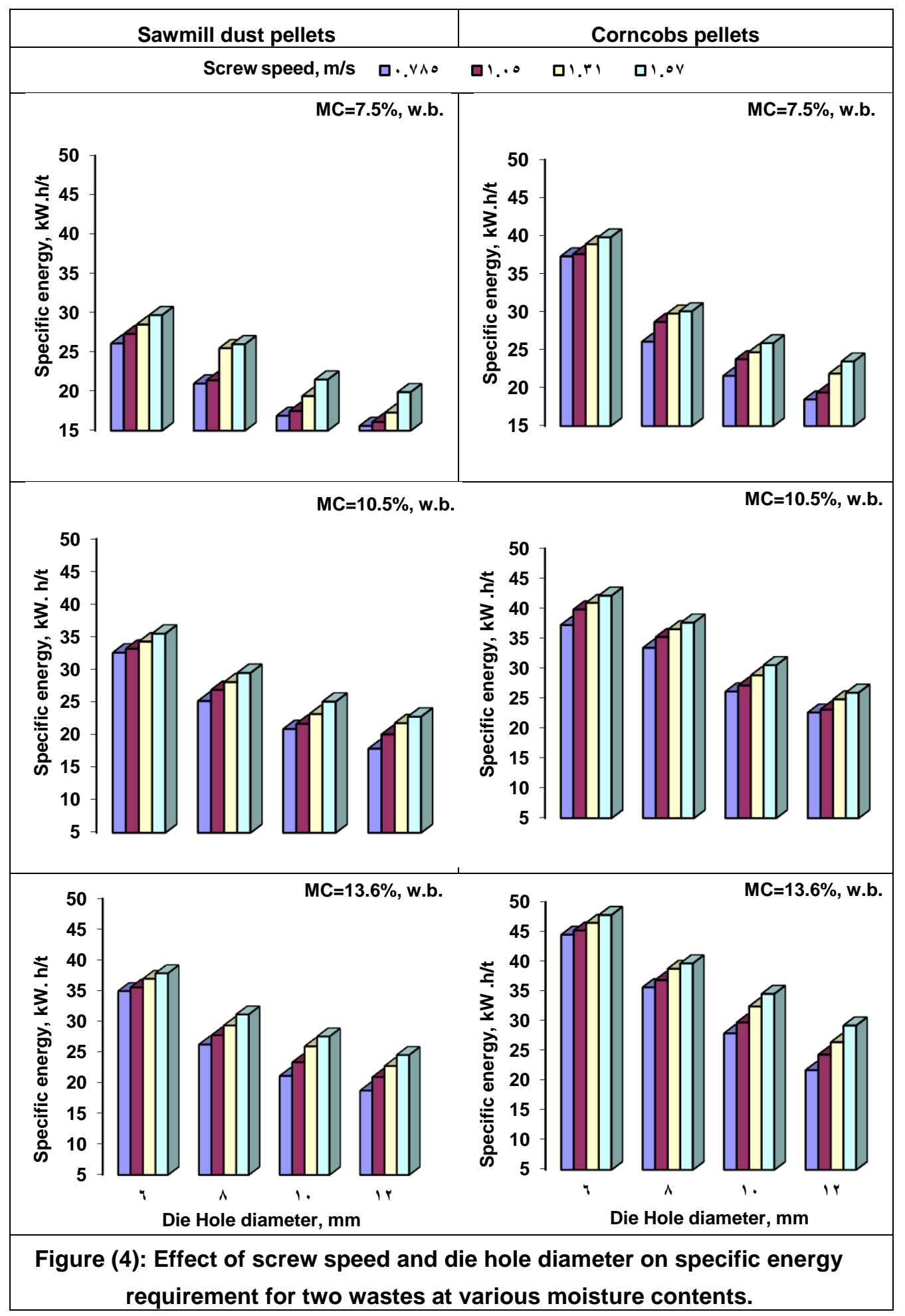


Table 1: combustion test results of pellets and loose materials.

\begin{tabular}{|c|c|c|c|}
\hline \multicolumn{2}{|c|}{ Materials } & $\begin{array}{c}\text { Average CO content } \\
\left(\mathbf{m g} / \mathbf{m}^{\mathbf{3}}\right)\end{array}$ & $\begin{array}{c}\text { Average flue gas } \\
\text { temperature }\left({ }^{\mathbf{0}} \mathbf{C}\right)\end{array}$ \\
\hline Sawmill & Raw materials & 1244 & 53.6 \\
dust & Pellets & 623 & 78.4 \\
\hline Corncubs & Raw materials & 1538 & 49.3 \\
& Pellets & 710 & 72.5 \\
\hline
\end{tabular}

\section{CONCLUSIONS}

1. The finer sawdust resulted in higher productivity, pellets density, durability and lower specific energy than the coarser corn cob grinds.

2. The productivity of machine for sawdust pellets was higher value by about $7 \%$ than the productivity of corncobs pellets.

3. The pellets density ranged from 0.81 to $1.24 \mathrm{~g} / \mathrm{cm}^{3}$ for sawdust and form 0.76 to $0.94 \mathrm{~g} / \mathrm{cm}^{3}$ for corncobs.

4. The durability of sawdust pellets was higher value by about $15.6 \%$ for corncobs pellets.

5. The energy requirement of sawdust pellets was lower value by about $41.7 \%$ than energy requirement for corncobs pellets.

6. The combustion test showed that the sawmill dust pellets at $6 \mathrm{~mm}$ diameter with $7.5 \%$ moisture content provided the highest flue gas temperature $\left(78.4^{\circ} \mathrm{C}\right)$. Also, $\mathrm{CO}$ contents emitted for pellets were reduced by around $50 \%$ as compared with loose materials.

7. This means the application of pelleting technology can solve the phytosanitary, environmental and storage problems of agroprocessing wastes in Egypt. The farmer's household could cover its need for fossil fuels for cooking and baking by using biomass pellets, a renewable energy source. 


\section{REFERENCES}

Adapa P., L. Tabil, G. Schoenau (2009). Compression characteristics of selected ground agricultural biomass. Agricultural Engineering International: the CIGR E journal. Manuscript 1347 (I):1-19.

ASAE Standard (2004). American Society of Agricultural Engineers Standards, Engineering Practices, and Data. ASAE: St. Joseph, MI.

Bjorheden, R. (2006). Drivers behind the development of forest energy in Sweden. Biomass and Bioenergy, 30(4), 289-295.

Chevanan, N.; K. Muthukumarappan; K.A. Rosentrater and J. L. Julson (2007). Effect of die dimensions on extrusion processing parameters and properties of DDGS-based aquaculture feed. Cereal Chemistry, 84(4), 389-398.

Chevanan N.; K. A. Rosentrater and K. Muthukumarappan (2010). Effects of processing conditions on single screw extrusion of feed ingredients containing DDGS. Food Bioprocess Technology, 3:111-120.

Chin, O.C. and K.M. Siddiqui (2000). Characteristics of Some Biomass Briquettes Prepared under Modest Die Pressures. Biomass and Bioenergy, 18: 223-228.

El-Saeidy E. (2004). Renewable Energy in Agriculture in Egypt: Technological Fundamentals of Briquetting Cotton Stalks as a Biofuel Renewable Energy in Agriculture in Egypt. Ph. D Thesis, Humboldt University, Berlin, Germany.

Granada, E., L.M. López González, J.L. Míguez and J. Moran (2002).

Fuel lignocellulosic briquettes, die design and products study. Renewable Energy, 27:561-573. 
Hess, J.R., K.L.Kenney, L.P Ovard, E.M. Searcy and C.T. Wright (2009). Uniform-Format Solid Feedstock Supply System: A Commodity-Scale Design to Produce an Infrastructure-Compatible Bulk Solid from Lignocelluloses Biomass: 4-08-14752. Idaho National Laboratory, Bioenergy.

Jin Z. and S. Wang (2011). Specific energy requirement for compacting corncobs. Advanced material research, 148-149: 245-252.

Kaliyan N. and R.V. Morey (2006). Densification of corn stover. ASAE Paper No. 056134. St. Joseph, MI: ASABE.

Kaliyan N. and R.V. Morey (2007). Strategies to improve durability of switch grass briquettes. An ASABE paper number: 076182.

Mark, S. (2008). Feedstock and process variables influencing biomass densification. M. Sc. Thesis, Dep. of Agric. and Bioresource Eng., Unive. of Saskatchewan, Saskatoon, Canada.

Mani, S., L.G. Tabil and S. Sokhansanj (2006). Effects of compressive force, particle size and moisture content on mechanical properties of biomass pellets from grasses. Biomass and Bioenergy, 30: 648654.

Saptoadi H. (2006). The best biobriquette dimension and its particle size. Proceedings of The 2nd joint international conference on "Sustainable Energy and Environment". 21-23 November 2006, Bangkok, Thailand.

Shoughy, M. I., A. A. FL-Keway, and Y. T. Hendawy (2011). Rice bran pellets production by using expeller machine. Misr J. Ag. Eng., 28(4): 975-998.

Shukla C. Y.; K. Muthukumarappan and J. L Julso. (2005). Effect of single screw extruder die temperature, amount of distillers dried 
grains with solubles (DDGS) and initial moisture content on extrudates. Cereal Chemistry: 82(1), 34-37.

Sokhansanj, S., S. Mani, X. B., P. Zaini and L. Tabil (2005). Binderless pelletization of biomass. Presented at the ASAE. Paper No. 056061, USA.

Sokhansanj, S., A. Kumar, A.F. Turhollow (2006). Development and implementation of integrated biomass supply analysis and logistics model (IBSAL). Biomass Bioenergy, 30: 838-847.

Thomas $\boldsymbol{O}$. W. (2010). Factors affecting wood pellet durability. MS C. Thesis in Agric. Bio. Eng., The Pennsylvania State University Dep. of Agric. and Bio. Eng., USA.

Tumuluru, J. S., L. Tabil, A. Opoku, M. R. Mosqueda and O. Fadeyi (2010a). Effect of process variables on the quality characteristics of pelleted wheat distiller's dried grains with soluble, Biosystems Engineering 105(4): 466-475.

Tumuluru, J. S., C. T. Wright, K. L. Kenney and J. R. Hess (2010b). A Technical Review on Biomass Processing: Densification, Preprocessing, Modeling and Optimization. ASABE Meeting Presentation. Paper Number: 1009401.

Uppal, S. L. (1984). Electrical power. Published by 2-B Nath Market, Nai Srak, New Delhi, India.

Van Dam, J.E.G., M.J.A. van den Oever, W. Teunissen, E.R.P. Keijsers and A.G. Peralta (2004). Process for production of high density/high performance binderless boards from whole coconut husk. Part 1: lignin as intrinsic thermosetting binder resin. Industrial Crops and Products, 19: 207-216. 


\section{الملخص العربى \\ تكنولوجيا إنتاج الكتلة الحيوية من مخلفات التصنيع الزراعي \\ باستخدام ألثة الكبس المستمر من ملهر \\ د/ محمد إسماعيل شوغى}

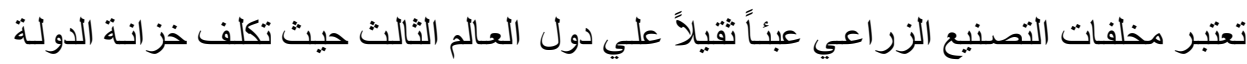

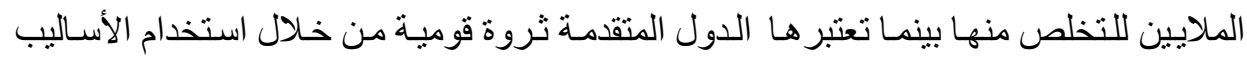

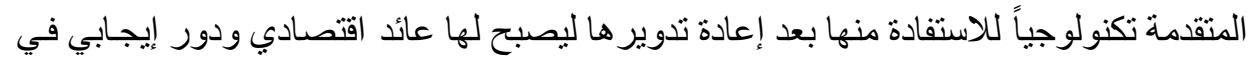

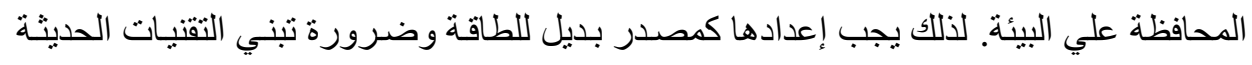

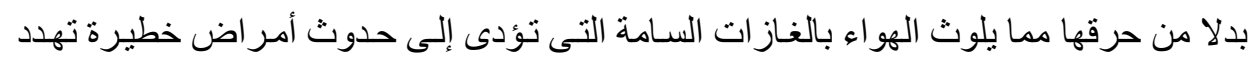

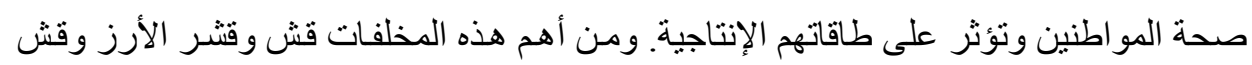

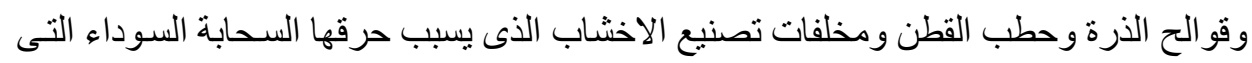

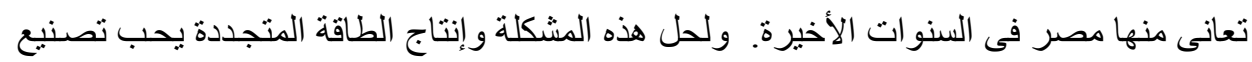

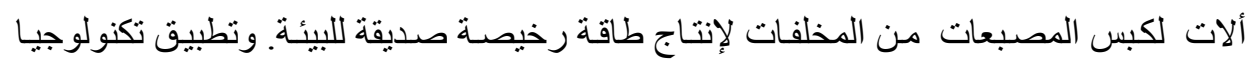

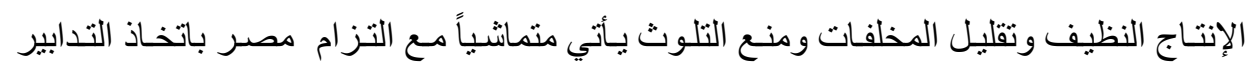

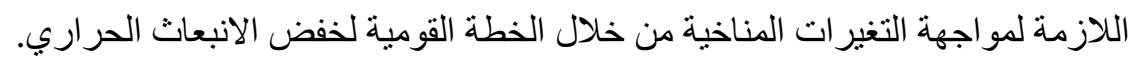

أهداف البحث:

1. دراسة إمكانية إنتاج مصبعات الكتلة الحيويـة من مخلفات التصنيع الزر اعي مثل نشارة

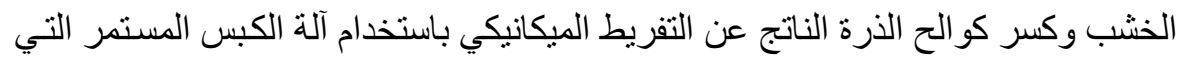

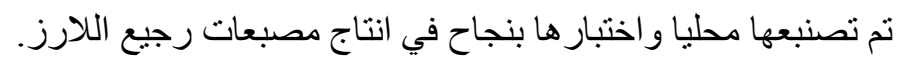

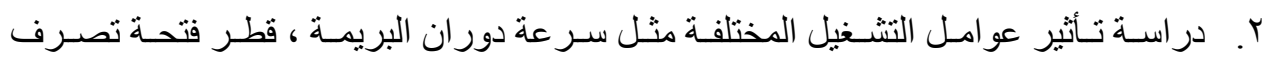

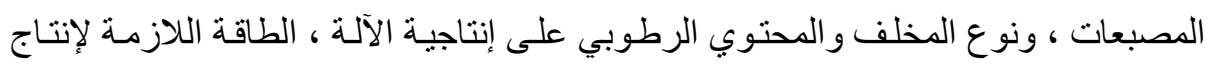

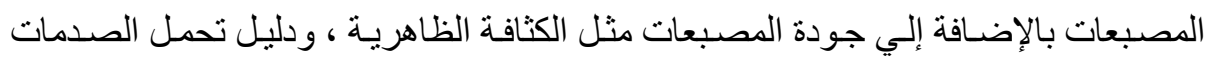

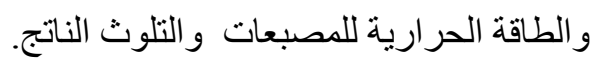

أهم النتائج:

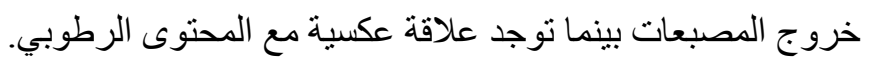

* معهر بحوث الهندسة الزراعيةـ الاقي- جيزة - مصر. 


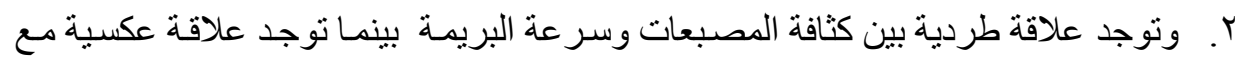

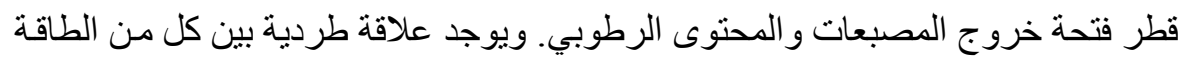

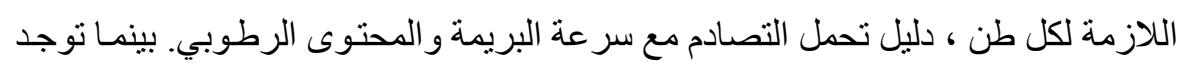
علاقة عكسية مع قطر فتحة خروج المصبعات.

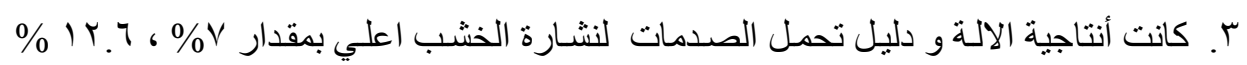

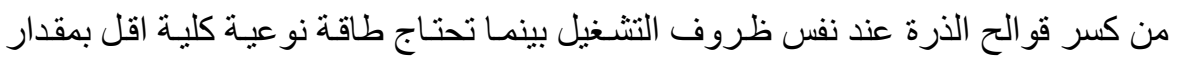
$\% \leqslant 1 . V$

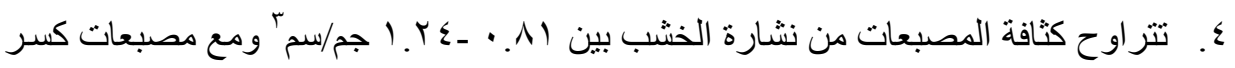

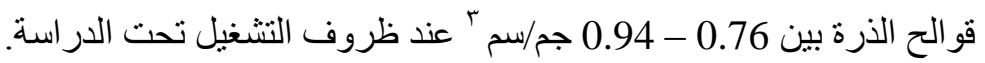

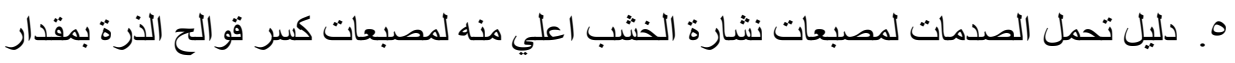
( 10.7 \% 10.7

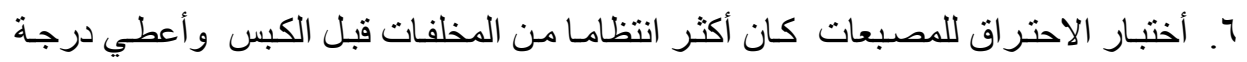

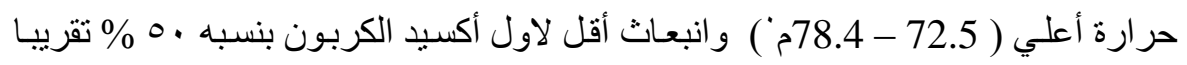
مما يجعلها مصدر للطاقه رخيص وصديق للبيئه.

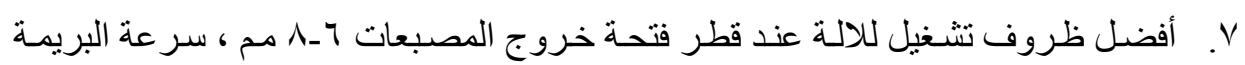

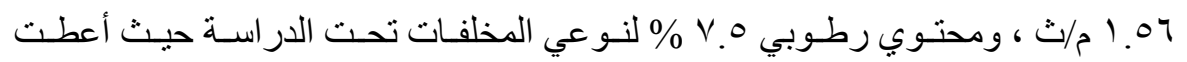

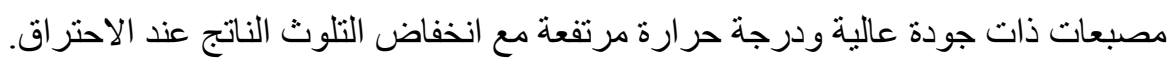

